\title{
Caledonian high-pressure metamorphism in the Strona-Ceneri Zone (Southern Alps of southern Switzerland and northern Italy)
}

\author{
LEANDER Franz ${ }^{1} \&$ Rolf L. RomeR ${ }^{2}$
}

Key words: Strona-Ceneri Zone, southern Alps, eclogites, PTtd-path, U-Pb dating of zircon and rutile, Ordovician subduction and collision

\section{ABSTRACT}

The Strona-Ceneri Zone comprises a succession of polymetamorphic, pre-Alpidic basement rocks including ortho- and paragneisses, metasedimentary schists, amphibolites, and eclogites. The rock pile represents a Late Proterozoic or Palaeozoic subduction accretion complex that was intruded by Ordovician granitoids. Eclogites, which occur as lenses within the ortho-paragneiss succession and as xenoliths within the granitoids record a subduction related high-pressure event (D1) with peak metamorphic conditions of $710 \pm 30^{\circ} \mathrm{C}$ at $21.0 \pm 2.5 \mathrm{kbar}$. After isothermal uplift, the eclogites experienced a Barrowtype (D2) tectonometamorphic overprint under amphibolite facies conditions (570-630 ${ }^{\circ} \mathrm{C}$, 7-9 kbar). U-Pb dating on zircon of the eclogites gives a metamorphic age of $457 \pm 5 \mathrm{Ma}$, and syn-eclogite facies rutile gives a ${ }^{206} \mathrm{~Pb} /{ }^{238} \mathrm{U}$ age of $443 \pm 19$ Ma classifying the subduction as a Caledonian event. These data show that the main tectonometamorphic evolution of the Strona-Ceneri Zone most probably took place in a convergent margin scenario, in which accretion, eclogitization of MOR-basalt, polyphase (D1 and D2) deformation, anatexis and magmatism all occurred during the Ordovician. Caledonian high-pressure metamorphism, subsequent magmatism and Barrow-type metamorphism are believed to be related to subduction and collision within the northern margin of Gondwana.

\section{ZUSAMMENFASSUNG}

Die Strona-Ceneri Zone baut sich aus einer Abfolge polymetamorpher, präalpidischer Kristallingesteine auf und umfasst Ortho- und Paragneise, metasedimentäre Schiefer, Amphibolite und Eklogite. Die Gesteinsserie repräsentiert einen spätproterozoischen oder paläozoischen Subduktions-AkkretionsKomplex, der von ordovizischen Granitoiden intrudiert wurde. Eklogite, die in Form von Linsen innerhalb der Ortho- und Paragneisfolge auftreten und überdies Xenolithe in Granitoiden bilden, zeichnen ein subduktionsbezogenes Hochdruckereignis (D1) auf, das bei Temperaturen von $710 \pm 30^{\circ} \mathrm{C}$ und Drucken von $21.0 \pm 2.5$ kbar ablief. Nach einer zunächst isothermalen Exhumierung erfuhren die Eklogite eine tektonometamorphe Überprägung (D2) vom Barrow-Typ unter amphibolitfaziellen Metamorphosebedingungen (570$630{ }^{\circ} \mathrm{C}, 7-9 \mathrm{kbar}$ ). Eine U-Pb Datierung an Zirkonen liefert ein metamorphes Alter von $457 \pm 5 \mathrm{Ma}$ während syn-eklogitfazielle Rutile ein ${ }^{206} \mathrm{~Pb} / 238 \mathrm{U}$-Alter von $443 \pm 19 \mathrm{Ma}$ anzeigen, was die Subduktion als kaledonisches Ereignis kennzeichnet. Diese Daten zeigen, dass ein Grossteil der tektonometamorphen Entwicklung der Strona-Ceneri Zone höchstwahrscheinlich im Bereich eines kovergenten Plattenrandes stattfand. Hierbei erfolgten die Akkretion, die Eklogitisierung der MOR-Basalte, die polyphase Deformation (D1 und D2) sowie Anatexis und Magmatismus allesamt im Ordovizium. Die kaledonische Hochdruck-Metamorphose, der nachfolgende Magmatismus und die metamorphe Überprägung vom Barrow-Typ werden als Folge von Subduktions- und Kollisionsprozessen am Nordrand von Gondwana interpretiert.

\section{Introduction}

The Strona-Ceneri Zone (SCZ) forms a SW-NE striking, preAlpine basement unit in the western part of the southern Alps (Fig. 1), which comprises gneisses and schists of sedimentary origin (metagreywacke and metapelite), metagranitoids, calcsilicate rocks, banded amphibolites and eclogites (for reference see Bächlin 1937; Spicher 1940; Graeter 1951; Boriani et al. 1977; Zurbriggen et al. 1997). Schmid (1968) first coined the term "Strona-Ceneri-Zone", which is synonymous with the "Serie de Laghi" of Boriani et al. (1977). The SCZ forms a crustal segment between amphibolite to granulite facies rocks of the Ivrea-Verbano Zone to the NW and unmetamorphosed, Permo-Mesozoic sediments to the $\mathrm{S}$ and SE. Some workers interpreted the SCZ as the originally intermediate part of a tilted crustal section with progressively deeper crustal levels exposed to the NW (e.g., Fountain 1976; Fountain \& Salisbury 1981). Other workers (e.g., Boriani et al. 1990), have long maintained that the SCZ was never tilted and that the subvertical dip of its compositional banding and schistosity is a Variscan feature.

Recent work shows that the main tectonometamorphic and magmatic event in the SCZ is Early Palaeozoic. The metagranitoids yield Ordovician intrusive ages as evident by U-Pb ages on zircon (cf. Pidgeon et al. 1970; Köppel \& Grünenfelder

\footnotetext{
${ }^{1}$ Mineralogisch-Petrographisches Institut Universität Basel, Bernoullistrasse 30, CH-4056 Basel, Switzerland. E-mail: leander.franz@unibas.ch

${ }^{2}$ GeoFoschungsZentrum Potsdam, Telegrafenberg, D-14473 Potsdam, Germany. E-mail: romer@gfz-potsdam.de
} 


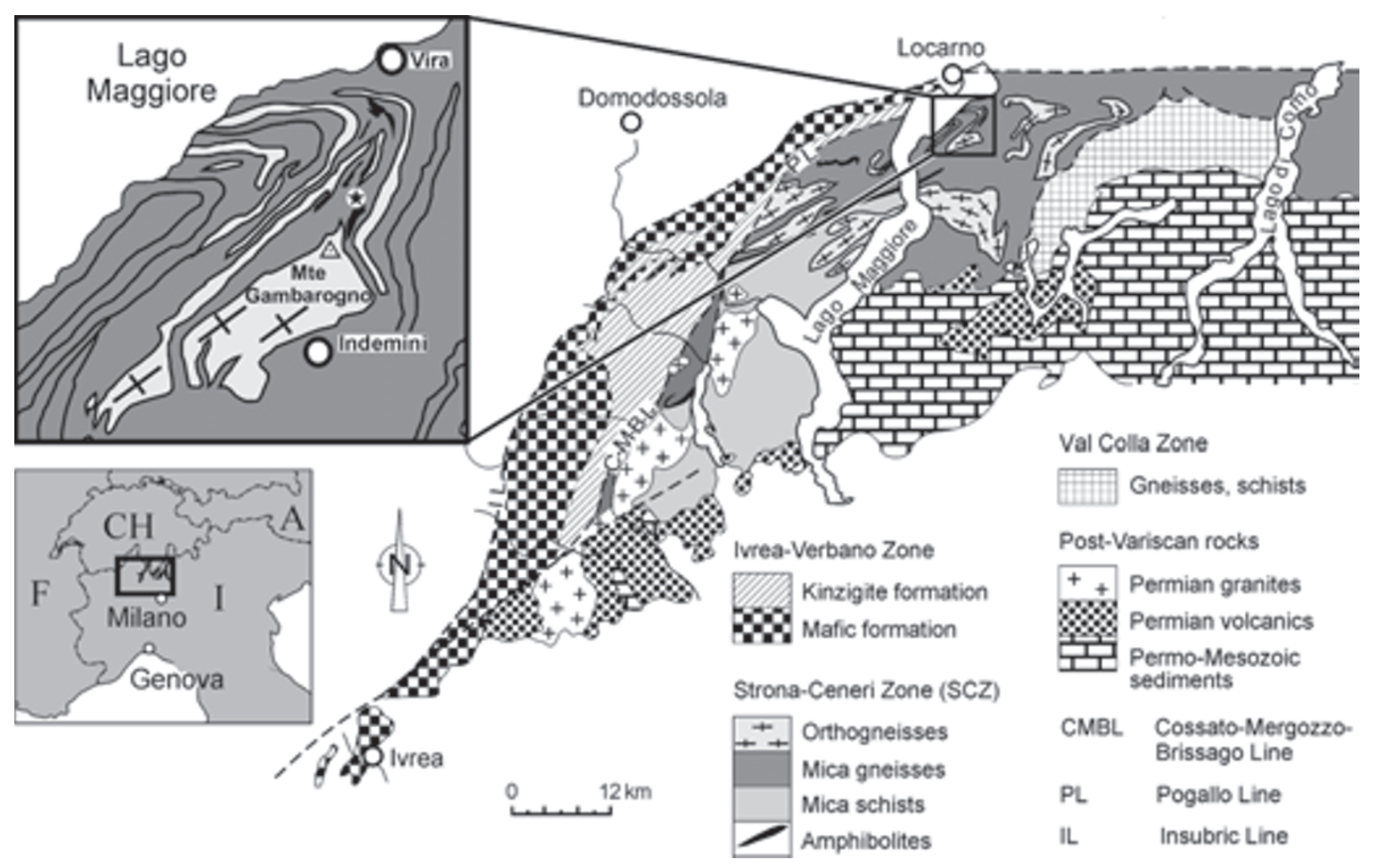

Fig. 1. Geological map of the western part of the Southern Alps (modified from Boriani et al. 1977, Zingg et al. 1990); inlyer shows Monte Gambarogno area with eclogite sample location (star; Swiss Coordinates 708.091; 108.345).

1971; Ragettli 1993; Zurbriggen et al. 1997) and Rb-Sr whole rock geochronology (cf. Boriani et al. 1983). The same applies to the age of the main tectonometamorphic overprint (D2), which created the penetrative S2 foliation and took place under Barrovian amphibolite facies conditions $\left(570-630{ }^{\circ} \mathrm{C}\right.$ at 7-9 kbar, cf. Romer \& Franz 1998; Handy et al. 1999). A Middle Carboniferous (D3) event led to the formation of km-scale folds, so-called "Schlingen" (Zurbriggen et al. 1998; Handy et al. 1999), while the southern margin of the SCZ and the Val Colla Zone were affected by a penetrative (D4), greenschist facies mylonitic deformation in the Middle to Upper Carboniferous (Janott 1996; Handy et al. 1999). Similar to the neighbouring Ivrea-Verbano Zone in the north, the SCZ only experienced a local, sub-greenschist facies overprint (Zingg 1990) in the Alpine event.

The chronology of early events in the SCZ is problematic. In syn-tectonic metagranitoids ("Ceneri-gneisses"), pre-intrusive D1 structures are found in fine-grained, metapelitic xenoliths in the undeformed central part of these granitoids. The early, pre-granitoid foliation in these xenoliths has been termed $\mathrm{S}_{1 \mathrm{a}}$ by Handy (1986) and $\mathrm{S}_{\mathrm{X}}$ by Boriani et al. (1990). The mineral assemblage biotite - muscovite \pm garnet, kyanite, and staurolite indicates a relatively high-pressure amphibolite metamorphism during the D1 deformation (Zurbriggen 1996; Zurbriggen et al. 1997).

The age of an early phase of high-pressure (HP) deformation and metamorphism revealed by foliated eclogitic pods within amphibolite lenses is not known. These mafic lenses are intercalated with micaceous schists and gneisses in the Monte Gambarogno area (located at the northeastern margin of Lago Maggiore, see Fig. 1; Buletti 1983; Borghi 1988). The protoliths of the metabasites were oceanic basalts as indicated by their distinct MORB composition (Buletti 1983; Giobbi-Origoni et al. 1997). The eclogites show a blurred S1 foliation and are boudinaged within the S2 schistosity. The boudinage was connected with a strong retrograde amphibolite facies overprint, which is particularly strong towards the contact with the surrounding gneisses (Zurbriggen et al. 1997). This relationship clearly indicates that HP-metamorphism pre-dated regional D2 deformation. This observation is confirmed by the occurrence of xenoliths of eclogitic garnet-amphibolite within Ordovician granitoids (Borghi 1989). The formation of these eclogites may have occurred during either Cadomian subduction (e.g., Schmid 1993), or Ordovician subduction (Zurbriggen 1996; Zurbriggen et al. 1997; Handy et al. 1999). 


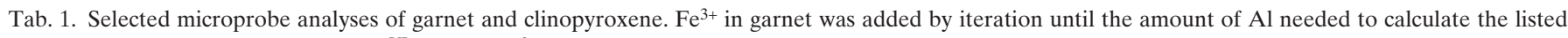

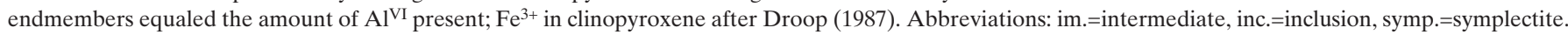

\begin{tabular}{|c|c|c|c|c|c|c|c|c|c|c|c|c|c|c|}
\hline $\begin{array}{l}\text { Garnet } \\
\text { wt.- \% }\end{array}$ & $\begin{array}{l}\text { IZ94-74 } \\
\text { Grt } \\
\text { rim }\end{array}$ & $\begin{array}{l}\text { IZ94-74 } \\
\text { Grt } \\
\text { im. }\end{array}$ & $\begin{array}{l}\text { IZ94-74 } \\
\text { Grt } \\
\text { core }\end{array}$ & $\begin{array}{l}\text { IZ94-74 } \\
\text { Grt } \\
\text { core }\end{array}$ & $\begin{array}{l}\text { IZ94-74 } \\
\text { Grt } \\
\text { im. }\end{array}$ & $\begin{array}{l}\text { IZ94-74 } \\
\text { Grt } \\
\text { rim }\end{array}$ & Clinopyroxene & $\begin{array}{l}\text { IZ94-74 } \\
\text { Omp } \\
\text { inc. }\end{array}$ & $\begin{array}{l}\text { IZ94-74 } \\
\text { Omp } \\
\text { inc. }\end{array}$ & $\begin{array}{l}\text { IZ94-74 } \\
\text { Omp } \\
\text { matrix }\end{array}$ & $\begin{array}{l}\text { IZ94-74 } \\
\text { Omp } \\
\text { matrix }\end{array}$ & $\begin{array}{l}\text { IZ93-74 } \\
\text { Di } \\
\text { symp. }\end{array}$ & $\begin{array}{l}\text { IZ94-74 } \\
\text { Di } \\
\text { symp. }\end{array}$ & $\begin{array}{l}\text { IZ94-74 } \\
\text { Di } \\
\text { symp. }\end{array}$ \\
\hline $\mathrm{SiO}_{2}$ & 38.54 & 38.34 & 38.42 & 38.36 & 38.18 & 38.20 & $\mathrm{SiO}_{2}$ & 55.60 & 55.70 & 55.24 & 55.19 & 54.29 & 54.10 & 53.74 \\
\hline $\mathrm{TiO}_{2}$ & 0.07 & 0.16 & 0.17 & 0.14 & 0.19 & 0.03 & $\mathrm{TiO}_{2}$ & 0.11 & 0.09 & 0.11 & 0.12 & 0.04 & 0.07 & 0.04 \\
\hline $\mathrm{Al}_{2} \mathrm{O}_{3}$ & 21.57 & 21.27 & 21.25 & 21.39 & 21.25 & 21.32 & $\mathrm{Al}_{2} \mathrm{O}_{3}$ & 10.88 & 9.90 & 9.73 & 9.56 & 3.32 & 3.03 & 2.66 \\
\hline $\mathrm{Cr}_{2} \mathrm{O}_{3}$ & 0.01 & 0.03 & 0.03 & 0.00 & 0.01 & 0.04 & $\mathrm{Cr}_{2} \mathrm{O}_{3}$ & 0.01 & 0.03 & 0.01 & 0.04 & 0.02 & 0.01 & 0.01 \\
\hline $\mathrm{Fe}_{2} \mathrm{O}_{3}$ & 0.09 & 0.41 & 0.18 & 0.09 & 0.56 & 0.20 & $\mathrm{Fe}_{2} \mathrm{O}_{3}$ & 1.13 & 0.52 & 0.00 & 0.71 & 0.00 & 0.36 & 0.00 \\
\hline $\mathrm{MgO}$ & 4.38 & 4.25 & 4.34 & 4.40 & 4.18 & 5.24 & $\mathrm{MgO}$ & 7.89 & 8.30 & 9.08 & 9.09 & 11.43 & 13.34 & 13.16 \\
\hline $\mathrm{CaO}$ & 10.56 & 10.73 & 11.08 & 10.99 & 10.95 & 8.51 & $\mathrm{CaO}$ & 12.56 & 14.05 & 14.99 & 15.14 & 19.54 & 20.44 & 21.33 \\
\hline $\mathrm{MnO}$ & 0.49 & 0.54 & 0.60 & 0.62 & 0.60 & 0.65 & $\mathrm{MnO}$ & 0.03 & 0.01 & 0.06 & 0.04 & 0.12 & 0.05 & 0.07 \\
\hline $\mathrm{FeO}$ & 24.00 & 23.90 & 22.88 & 22.99 & 23.64 & 24.53 & $\mathrm{FeO}$ & 4.85 & 5.45 & 4.49 & 4.26 & 10.09 & 5.37 & 7.01 \\
\hline $\mathrm{Na}_{2} \mathrm{O}$ & 0.02 & 0.03 & 0.05 & 0.03 & 0.06 & 0.01 & $\mathrm{Na}_{2} \mathrm{O}$ & 6.79 & 6.13 & 5.37 & 5.65 & 1.99 & 2.02 & 1.26 \\
\hline Total: & 99.72 & 99.68 & 99.01 & 99.01 & 99.62 & 98.72 & $\mathrm{~K}_{2} \mathrm{O}$ & 0.02 & 0.00 & 0.02 & 0.00 & 0.02 & 0.00 & 0.00 \\
\hline \multicolumn{7}{|c|}{ Structural formula $(12 O)$} & Total: & 99.87 & 100.18 & 99.09 & 99.80 & 100.86 & 98.79 & 99.29 \\
\hline $\mathrm{T} \quad \mathrm{Si}$ & 3.007 & 3.000 & 3.014 & 3.009 & 2.991 & 3.008 & \multicolumn{8}{|c|}{ Structural formula (6 O) } \\
\hline $\mathrm{Fe}^{3+}$ & 0.000 & 0.000 & 0.000 & 0.000 & 0.009 & 0.000 & $\mathrm{~T} \quad \mathrm{Si}$ & 1.988 & 1.994 & 1.991 & 1.981 & 1.999 & 1.999 & 1.992 \\
\hline Total T: & 3.007 & 3.000 & 3.014 & 3.009 & 3.000 & 3.008 & $\mathrm{Al}$ & 0.012 & 0.006 & 0.009 & 0.019 & 0.001 & 0.001 & 0.008 \\
\hline $\mathrm{Y} \quad \mathrm{Ti}$ & 0.004 & 0.009 & 0.010 & 0.008 & 0.011 & 0.002 & Total T: & 2.000 & 2.000 & 2.000 & 2.000 & 2.000 & 2.000 & 2.000 \\
\hline $\mathrm{Al}$ & 1.984 & 1.962 & 1.965 & 1.978 & 1.962 & 1.978 & M1 & 0.447 & 0.412 & 0.404 & 0.385 & 0.143 & 0.131 & 0.108 \\
\hline $\mathrm{Cr}$ & 0.000 & 0.002 & 0.002 & 0.000 & 0.000 & 0.002 & $\mathrm{Fe}^{3+}$ & 0.030 & 0.014 & 0.000 & 0.019 & 0.000 & 0.010 & 0.000 \\
\hline $\mathrm{Fe}^{3+}$ & 0.005 & 0.024 & 0.011 & 0.006 & 0.024 & 0.012 & $\mathrm{Cr}$ & 0.000 & 0.001 & 0.000 & 0.001 & 0.001 & 0.000 & 0.000 \\
\hline Total Y: & 1.994 & 1.997 & 1.987 & 1.992 & 1.998 & 1.994 & $\mathrm{Ti}$ & 0.003 & 0.002 & 0.003 & 0.003 & 0.001 & 0.002 & 0.001 \\
\hline $\mathrm{X} \quad \mathrm{Mg}$ & 0.509 & 0.496 & 0.508 & 0.514 & 0.489 & 0.615 & $\mathrm{Mg}$ & 0.386 & 0.417 & 0.464 & 0.468 & 0.572 & 0.699 & 0.686 \\
\hline $\mathrm{Ca}$ & 0.883 & 0.900 & 0.932 & 0.924 & 0.920 & 0.718 & $\mathrm{Fe}^{2+}$ & 0.133 & 0.154 & 0.129 & 0.123 & 0.283 & 0.158 & 0.205 \\
\hline Mn & 0.032 & 0.036 & 0.040 & 0.041 & 0.040 & 0.043 & Total M1: & 1.000 & 1.000 & 1.000 & 1.000 & 1.000 & 1.000 & 1.000 \\
\hline $\mathrm{Fe}^{2+}$ & 1.566 & 1.564 & 1.502 & 1.508 & 1.549 & 1.616 & M2 & 0.034 & 0.026 & 0.024 & 0.018 & 0.055 & 0.036 & 0.042 \\
\hline $\mathrm{Na}$ & 0.003 & 0.005 & 0.008 & 0.005 & 0.009 & 0.002 & $\mathrm{Fe}^{2+}$ & 0.012 & 0.009 & 0.007 & 0.005 & 0.027 & 0.008 & 0.012 \\
\hline Total X: & 2.994 & 3.001 & 2.989 & 2.992 & 3.006 & 2.993 & $\mathrm{Mn}$ & 0.001 & 0.000 & 0.002 & 0.001 & 0.004 & 0.002 & 0.002 \\
\hline Total: & 7.995 & 7.999 & 7.991 & 7.993 & 8.004 & 7.995 & $\mathrm{Ca}$ & 0.481 & 0.539 & 0.579 & 0.582 & 0.771 & 0.809 & 0.847 \\
\hline Endmembers: & & & & & & & $\mathrm{Na}$ & 0.471 & 0.425 & 0.375 & 0.393 & 0.142 & 0.145 & 0.090 \\
\hline Uvarowite: & 0.0 & 0.1 & 0.1 & 0.0 & 0.0 & 0.1 & $\mathrm{~K}$ & 0.001 & 0.000 & 0.001 & 0.000 & 0.001 & 0.000 & 0.000 \\
\hline Andradite: & 0.5 & 1.7 & 1.0 & 0.7 & 1.8 & 0.7 & Total M2: & 1.000 & 1.000 & 0.987 & 1.000 & 1.000 & 1.000 & 0.994 \\
\hline Grossular: & 29.0 & 28.2 & 30.1 & 30.2 & 28.9 & 23.2 & Total: & 4.000 & 4.000 & 3.987 & 4.000 & 4.000 & 4.000 & 3.994 \\
\hline Almandine: & 52.4 & 52.2 & 50.4 & 50.5 & 51.7 & 54.0 & \multicolumn{8}{|c|}{ Endmembers (Banno, 1959): } \\
\hline Spessartine: & 1.1 & 1.2 & 1.3 & 1.4 & 1.3 & 1.4 & Jadeite: & 46.3 & 42.7 & 39.4 & 38.4 & 15.6 & 14.1 & 9.7 \\
\hline \multirow[t]{2}{*}{ Pyrope: } & 17.0 & 16.6 & 17.0 & 17.2 & 16.3 & 20.5 & Aegirine: & 3.2 & 1.4 & 0.0 & 1.9 & 0.0 & 1.1 & 0.0 \\
\hline & & & & & & & Augite: & 50.5 & 55.9 & 60.6 & 59.7 & 84.4 & 84.8 & 90.3 \\
\hline
\end{tabular}

This paper presents new petrologic data as well as $\mathrm{U}-\mathrm{Pb}$ data of zircon and rutile from the Monte Gambarogno eclogites, which help to constrain the early tectonometamorphic history of the SCZ.

\section{Petrology, mineral chemistry and thermobarometry of the Monte Gambarogno eclogites}

\subsection{Sample location and microprobe analytical methods}

Eclogite sample IZ94-74 originates from the northern slope of Monte Gambarogno, where eclogites form large, lens-shaped boudins within an extended layer of garnet amphibolite (Fig. 1). Microprobe investigations were performed at the GFZ Potsdam using a CAMECA SX50 and at the university of Freiberg using a JEOL JXA-8900R. Major and minor elements were determined at $15 \mathrm{kV}$ acceleration voltage and a beam current of $20 \mathrm{nA}$ with counting times of $20 \mathrm{~s}$ for $\mathrm{Si}, \mathrm{Al}, \mathrm{Mg}, \mathrm{Ca}, \mathrm{Sr}, \mathrm{Ba}$ and
$\mathrm{K}$, and $30 \mathrm{~s}$ for $\mathrm{Fe}, \mathrm{Ni}, \mathrm{Na}, \mathrm{Cr}, \mathrm{Mn}$ and $\mathrm{Ti}$. The integrated standard sets of CAMECA, the MAC ${ }^{\mathrm{TM}}$ standard set as well as the standard set of the Smithonian Institute (cf. Jarosewich et al. $1980)$ were used for reference. The analytical error of the microprobe for main elements ( $>10 \mathrm{wt} . \%)$ is less than $1 \%$, for main and minor elements (2-10 wt.- $\%)$ it is about $2 \%$, and for minor elements $(<2 \mathrm{wt} .-\%)$ it is more than $5 \%$. Selected microprobe analyses of the representative minerals are listed in Tables 1 and 2; mineral abbreviations are after Kretz (1983) and Phg $=$ phengite, Uvar $=$ uvarowite. The entire dataset of the analyses is available from the first author on request.

\subsection{Petrography}

Eclogite IZ94-74 is a greenish-blue rock, which displays mmsized, euhedral garnet crystals within a in a fine- to medium grained groundmass (Fig. 2a). Due to the strong retrograde overprint, no traces of the eclogitic S1 foliation are preserved. Garnet 


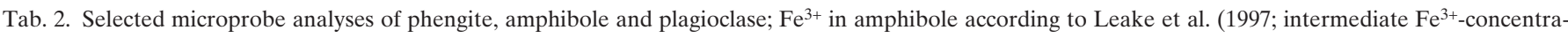
tion). Abbreviations see Fig. 1.

\begin{tabular}{|c|c|c|c|c|c|c|c|c|c|c|c|c|c|c|}
\hline $\begin{array}{l}\text { Phengite } \\
\text { wt.-\% }\end{array}$ & $\begin{array}{l}\text { IZ-94-74 } \\
\text { Phg } \\
\text { core }\end{array}$ & $\begin{array}{l}\text { IZ-94-74 } \\
\text { Phg } \\
\text { core }\end{array}$ & $\begin{array}{l}\text { IZ-94-74 } \\
\text { Phg } \\
\text { core }\end{array}$ & $\begin{array}{l}\text { IZ-94-74 } \\
\text { Phg } \\
\text { core }\end{array}$ & $\begin{array}{l}\text { Amphibole } \\
\text { wt.-\% }\end{array}$ & $\begin{array}{l}\text { IZ94-74 } \\
\text { Prg } \\
\text { inc. }\end{array}$ & $\begin{array}{l}\text { IZ94-74 } \\
\text { Ed } \\
\text { core }\end{array}$ & $\begin{array}{l}\text { IZ94-74 } \\
\text { Ed } \\
\text { core }\end{array}$ & $\begin{array}{l}\text { IZ94-74 } \\
\text { Mg-Hbl } \\
\text { rim }\end{array}$ & $\begin{array}{l}\text { Plagioclase } \\
\text { wt.-\% }\end{array}$ & $\begin{array}{l}\text { IZ94-74 } \\
\text { Pl } \\
\text { symp. }\end{array}$ & $\begin{array}{l}\text { IZ94-74 } \\
\text { Pl } \\
\text { symp. }\end{array}$ & $\begin{array}{l}\text { IZ94-74 } \\
\mathrm{Pl} \\
\text { rim }\end{array}$ & $\begin{array}{l}\text { IZ94-74 } \\
\text { Pl } \\
\text { mica layer }\end{array}$ \\
\hline $\mathrm{SiO}_{2}$ & 51.25 & 52.26 & 50.47 & 49.76 & $\mathrm{SiO}_{2}$ & 41.41 & 43.95 & 44.85 & 47.36 & $\mathrm{SiO}_{2}$ & 67.25 & 62.44 & 60.74 & 51.24 \\
\hline $\mathrm{TiO}_{2}$ & 0.43 & 0.48 & 0.48 & v0.48 & $\mathrm{TiO}_{2}$ & 1.26 & 1.20 & 1.50 & 0.52 & $\mathrm{Al}_{2} \mathrm{O}_{3}$ & 20.07 & 23.33 & 24.55 & 30.25 \\
\hline $\mathrm{Al}_{2} \mathrm{O}_{3}$ & 29.00 & 28.72 & 28.68 & 29.21 & $\mathrm{Al}_{2} \mathrm{O}_{3}$ & 15.55 & 10.43 & 9.38 & 8.83 & $\mathrm{MgO}$ & 0.01 & 0.02 & 0.02 & 0.00 \\
\hline $\mathrm{MgO}$ & 2.92 & 2.97 & 2.95 & 2.91 & $\mathrm{Fe}_{2} \mathrm{O}_{3}$ & 3.29 & 2.90 & 2.87 & 3.64 & $\mathrm{CaO}$ & 0.77 & 3.89 & 5.98 & 13.36 \\
\hline $\mathrm{CaO}$ & 0.00 & 0.00 & 0.01 & v0.00 & $\mathrm{Cr}_{2} \mathrm{O}_{3}$ & 0.05 & 0.01 & 0.02 & 0.03 & $\mathrm{MnO}$ & 0.03 & 0.02 & 0.00 & 0.00 \\
\hline $\mathrm{MnO}$ & 0.01 & v0.00 & 0.02 & v0.02 & $\mathrm{MgO}$ & 9.99 & 10.33 & 10.67 & 13.81 & $\mathrm{FeO}$ & 0.21 & 0.21 & 0.06 & 0.18 \\
\hline $\mathrm{FeO}$ & 1.32 & 1.34 & 1.30 & 1.34 & $\mathrm{CaO}$ & 10.29 & 10.59 & 10.53 & 10.72 & $\mathrm{BaO}$ & 0.00 & 0.01 & 0.03 & 0.00 \\
\hline $\mathrm{Na}_{2} \mathrm{O}$ & 0.21 & 0.18 & $\mathrm{v} 0.25$ & v0.24 & $\mathrm{MnO}$ & 0.17 & 0.07 & 0.11 & 0.13 & $\mathrm{Na}_{2} \mathrm{O}$ & 10.98 & 9.12 & 8.03 & 3.79 \\
\hline $\mathrm{K}_{2} \mathrm{O}$ & 10.88 & 10.81 & 10.94 & 10.79 & $\mathrm{FeO}$ & 12.62 & 14.81 & 14.93 & 10.24 & $\mathrm{~K}_{2} \mathrm{O}$ & 0.03 & 0.10 & 0.04 & 0.06 \\
\hline Total: & 96.02 & 96.76 & 95.10 & 94.74 & $\mathrm{Na}_{2} \mathrm{O}$ & 3.06 & 2.45 & 2.43 & 2.07 & Total: & 99.35 & 99.13 & 99.45 & 98.87 \\
\hline Structural for & mula $(11$ & O) & & & $\mathrm{K}_{2} \mathrm{O}$ & 0.42 & 0.23 & 0.20 & 0.24 & Cations $(8 \mathrm{O})$ & & & & \\
\hline $\mathrm{T} \quad \mathrm{Si}$ & 3.375 & 3.409 & 3.363 & 3.328 & Total: & 98.09 & 96.98 & 97.49 & 97.59 & $\mathrm{Si}$ & 2.961 & 2.784 & 2.712 & 2.354 \\
\hline $\mathrm{Al}$ & 0.625 & 0.591 & 0.637 & 0.672 & \multicolumn{5}{|c|}{ Structural formula (23 O) } & $\mathrm{Al}$ & 1.041 & 1.226 & 1.292 & 1.638 \\
\hline Total T: & 4.000 & 4.000 & 4.000 & 4.000 & $\mathrm{~T} \quad \mathrm{Si}$ & 6.112 & 6.601 & 6.696 & 6.888 & $\mathrm{Mg}$ & 0.001 & 0.001 & 0.001 & 0.000 \\
\hline $\mathrm{O} \quad \mathrm{Al}$ & 1.626 & 1.617 & 1.615 & 1.631 & $\mathrm{Al}$ & 1.888 & 1.399 & 1.304 & 1.112 & $\mathrm{Ca}$ & 0.036 & 0.186 & 0.286 & 0.658 \\
\hline $\mathrm{Ti}$ & 0.021 & 0.024 & 0.024 & 0.024 & Total T: & 8.000 & 8.000 & 8.000 & 8.000 & $\mathrm{Mn}$ & 0.001 & 0.001 & 0.000 & 0.000 \\
\hline $\mathrm{Mg}$ & 0.287 & 0.289 & 0.293 & 0.290 & $\mathrm{C} \quad \mathrm{Al}$ & 0.817 & 0.446 & 0.346 & 0.401 & $\mathrm{Fe}$ & 0.008 & 0.008 & 0.002 & 0.007 \\
\hline $\mathrm{Fe}$ & 0.073 & 0.073 & 0.072 & 0.075 & $\mathrm{Cr}$ & 0.005 & 0.001 & 0.003 & 0.004 & $\mathrm{Ba}$ & 0.000 & 0.000 & 0.001 & 0.000 \\
\hline $\mathrm{Mn}$ & 0.000 & 0.000 & 0.001 & 0.001 & $\mathrm{Fe}^{3+}$ & 0.365 & 0.328 & 0.323 & 0.399 & $\mathrm{Na}$ & 0.937 & 0.788 & 0.695 & 0.337 \\
\hline Total O: & 2.007 & 2.002 & 2.006 & 2.020 & $\mathrm{Ti}$ & 0.140 & 0.135 & 0.168 & 0.057 & $\mathrm{~K}$ & 0.002 & 0.006 & 0.002 & 0.003 \\
\hline $\mathrm{I} \quad \mathrm{Ca}$ & 0.000 & 0.000 & 0.000 & 0.000 & $\mathrm{Mg}$ & 2.198 & 2.313 & 2.375 & 2.994 & Total: & 4.988 & 5.000 & 4.991 & 4.997 \\
\hline $\mathrm{Na}$ & 0.026 & 0.023 & 0.033 & 0.032 & $\mathrm{Fe}^{2+}$ & 1.474 & 1.776 & 1.786 & 1.147 & \multicolumn{5}{|l|}{ Endmembers: } \\
\hline $\mathrm{K}$ & 0.914 & 0.899 & 0.930 & 0.921 & Total C: & 5.000 & 5.000 & 5.000 & 5.000 & Anorthite: & 3.7 & 19.0 & 29.1 & 65.9 \\
\hline Total I: & 0.941 & 0.922 & 0.963 & 0.952 & B $\quad \mathrm{Fe}^{2+}$ & 0.084 & 0.085 & 0.078 & 0.098 & Albite: & 96.1 & 80.4 & 70.6 & 33.8 \\
\hline Total: & 6.948 & 6.925 & 6.968 & 6.973 & $\mathrm{Mn}$ & 0.021 & 0.009 & 0.014 & 0.016 & Orthoclase: & 0.2 & 0.6 & 0.2 & 0.3 \\
\hline Endmembers: & & & & & $\mathrm{Ca}$ & 1.628 & 1.704 & 1.684 & 1.670 & Celsiane: & 0.0 & 0.0 & 0.1 & 0.0 \\
\hline Margarite: & 0.0 & 0.0 & 0.0 & 0.0 & $\mathrm{Na}$ & 0.267 & 0.202 & 0.223 & 0.216 & & & & & \\
\hline Paragonite: & 2.8 & 2.5 & 3.4 & 3.3 & Total B: & 2.000 & 2.000 & 2.000 & 2.000 & & & & & \\
\hline Ceadonite: & 37.5 & 40.9 & 36.3 & 32.8 & A $\mathrm{Na}$ & 0.609 & 0.512 & 0.481 & 0.367 & & & & & \\
\hline Muscovite: & 59.6 & 56.6 & 60.3 & 63.9 & $\mathrm{~K}$ & 0.078 & 0.044 & 0.038 & 0.045 & & & & & \\
\hline & & & & & Total A: & 0.687 & 0.555 & 0.519 & 0.413 & & & & & \\
\hline & & & & & Total: & 15.687 & 15.555 & 15.519 & 15.413 & & & & & \\
\hline
\end{tabular}

crystals often show corrosion at the rim formed by intergrowths of green hornblende, plagioclase, and quartz. The groundmass is mainly made up of plagioclase-diopside symplectites, which formed by the breakdown of omphacite (Figs. 2a,b), and of mmsized hornblende crystals showing brownish core sections and olive-green rims. Quartz grains are often rimmed by small seams of hornblende, whereas phengite, which is intensely retrograded to biotite, forms tiny lenses and layers (Fig. 2c). Accessories are apatite, rare zircon and rutile rimmed by ilmenite.

Microprobe profiles through garnet reveal relatively flat zonation patterns in the core sections of the crystals with Alm50${ }_{54}$ GAU(= Grs+Adr+Uvar) 28 -33 Prp Pr-18 $_{\text {Sps }}$ 0.5-1.7. Numerous inclusions of omphacite in the garnet core (Fig. 2a) demonstrate its growth during eclogite facies conditions. The composition of the garnet rim section strongly depends on the adjacent mineral assemblage. A distinct increase of pyrope component at the expense of grossular is found near clinopyroxene-plagioclase symplectites, whereas rim sections in contact with hornblende often show no significant change in the patterns (cf. Fig. 3). The $\mathrm{X}_{\mathrm{Mg}}$ in the garnet increases from $0.24-0.25$ in the core section to 0.28 at the rim near the symplectites.
Omphacite mainly occurs as inclusions in the core sections of garnet and as rare relics in the groundmass surrounded by symplectites of plagioclase - clinopyroxene \pm quartz (Figs. $2 \mathrm{a}, \mathrm{b})$. Jadeite contents of 30-46 mole- $\%$ are recorded in different grains while stoichiometry points to $\mathrm{Fe}^{3+}$-contents of 0 $18 \%$ of total iron. $\mathrm{X}_{\mathrm{Mg}}$ values of omphacite vary between 0.73 and 0.79 . Clinopyroxene in the symplectites is diopside (classification of Morimoto 1988) with jadeite contents of 9-16 mole$\%$. $\mathrm{Fe}^{3+}$-contents of $0-36 \%$ of total iron and highly variable $\mathrm{X}_{\mathrm{Mg}}$ values of $0.53-0.88$ are recorded in symplectites from different locations of the thin section.

Primary, mm-sized amphibole grains in the matrix reveal distinct zoning with brown, Al- and Ti-rich core domains and green rims. Microprobe analyses classify the core sections as pargasite and edenite (Leake et al. 1997), whereas the rim consists of Mg-hornblende. Brown edenitic and pargasitic amphibole inclusions are also found in the core section of garnet next to omphacite, which points to their growth under eclogite facies conditions. Late amphibole intergrown with plagioclase corroding the garnet rim and amphibole seams around quartz are Mg-hornblende (Fig. 2b). 

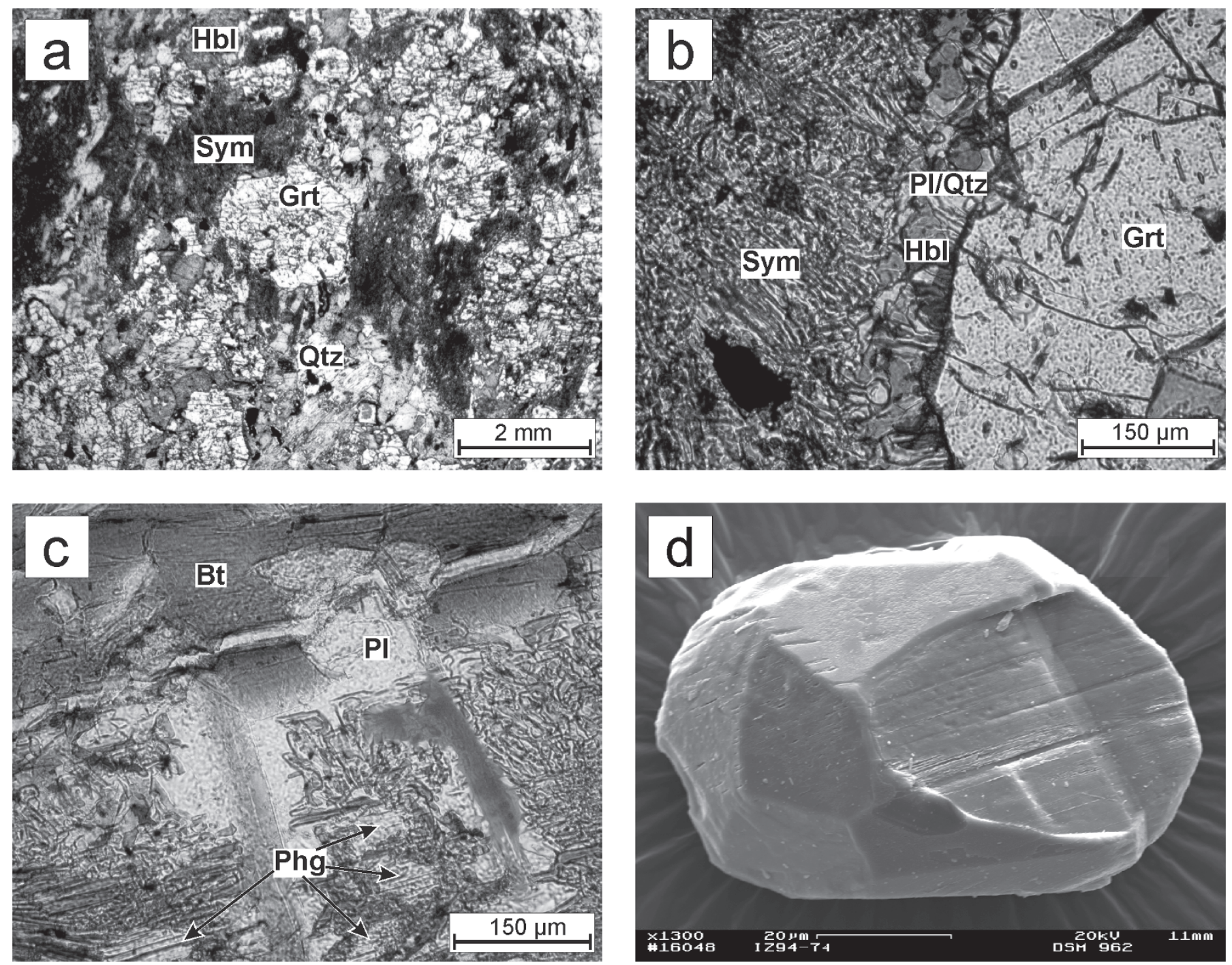

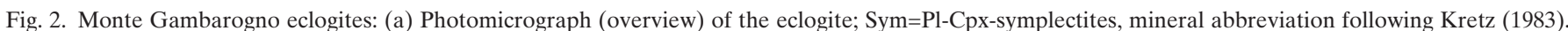

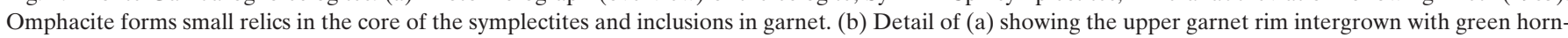

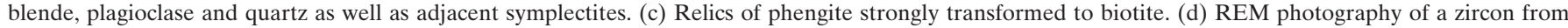
sample IZ94-74.

Phengite is only present as small, strongly corroded relic flakes mantled by secondary biotite (Fig. 2c). Analyses reveal $\mathrm{X}_{\mathrm{Mg}}$ values of 0.78-0.81, and Si contents of 3.33-3.41 p.f.u. corresponding to celadonite components of 33-41 mole-\%. Low paragonite components of 2-7 mole-\% are recorded (calculation of endmembers following Schliestedt 1980).

Plagioclase intergrown with diopside in the symplectites is albite and oligoclase with $\mathrm{An}_{3-19}$. These variations in composition occur within a few microns within the same symplectite. Plagioclase associated with $\mathrm{Mg}$-hornblende is oligoclase and andesine yielding $\mathrm{An}_{19-34}$. In some cases, distinct zoning is observed with increasing An-contents from core to rim of the plagioclase grains. Remarkable is the presence of granoblastic labradorite with $\mathrm{An}_{54-66}$ in mica-rich layers.

\subsection{Thermobarometry}

Metamorphic temperatures for the eclogite facies were determined using (1) the garnet-clinopyroxene $\mathrm{Fe}-\mathrm{Mg}$ exchange geothermometer of Krogh (2000) on omphacite inclusions in garnet; (2) the garnet-amphibole Fe-Mg-exchange geothermometer of Graham \& Powell (1984) on brown edenite inclusions in garnet; (3) the Ti-in-amphibole geothermometers of Colombi (1988) and of Ernst \& Liu (1998) and (4) the garnet-phengite Fe-Mg-exchange geothermometer of Green \& Hellman (1982). Metamorphic pressures for the eclogite facies were calculated using the equilibrium 


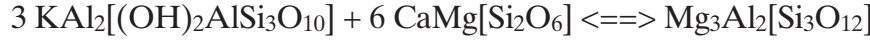

$$
\begin{aligned}
& \text { muscovite diopside pyrope } \\
& +2 \mathrm{Ca}_{3} \mathrm{Al}_{2}\left[\mathrm{Si}_{3} \mathrm{O}_{12}\right]+3 \mathrm{KAlMg}\left[(\mathrm{OH})_{2} \mathrm{Si}_{4} \mathrm{O}_{10}\right] \\
& \text { grossular } \mathrm{Mg} \text {-celadonite }
\end{aligned}
$$

calibrated by Waters \& Martin (1993; updated 1996) under consideration of the recommendations of Carswell et al. (1997), i.e. the activity model of Newton and Haselton (1981) for garnet, the activity model of Holland (1990) for omphacite and ideal mixing in phengite.

To get information about the maximum pressures during the HP-event, the garnet analysis with the highest value of aPrp ${ }^{*} \mathrm{a}_{\mathrm{Grs}}{ }^{2}$ from the centre of the garnet core (see Fig. 3), the omphacite inclusion with the highest jadeite content (i.e. $\mathrm{Jd}_{46.3}$ ), and the phengite with the highest Si-content (i.e. 3.41 p.f.u.) were chosen. PT-conditions of $710 \pm 30{ }^{\circ} \mathrm{C}$ at $21.0 \pm 2.5$ kbar were calculated using the geobarometer of Waters \&

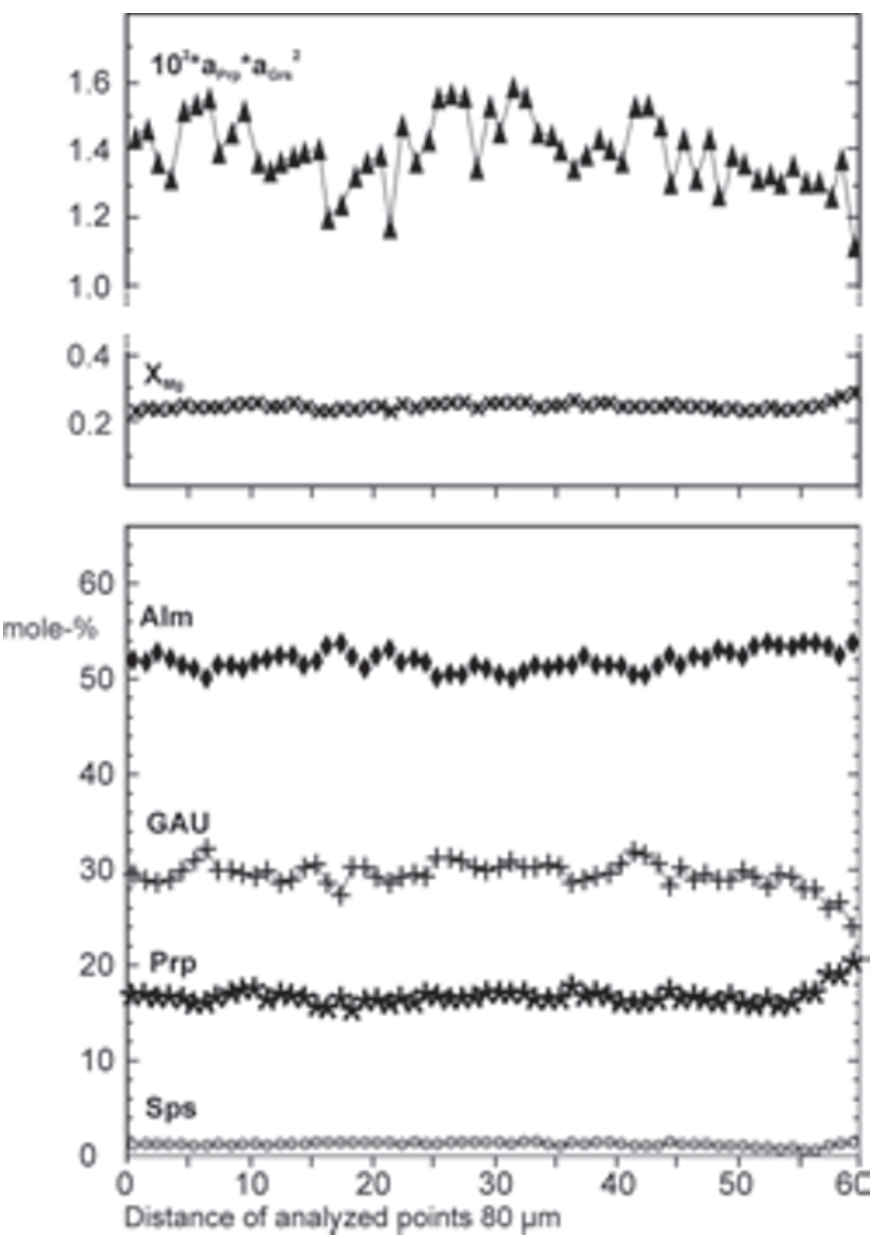

Fig. 3. Microprobe profile through garnet showing the endmember components (mineral abbreviations following Kretz 1983; GAU $=\mathrm{Grs}+\mathrm{Adr}+\mathrm{Uvar}$ ) as well as the $\mathrm{X}_{\mathrm{Mg}}$ and the aPrp ${ }^{*} \mathrm{arrs}^{2}$ values of the analysed points.
Martin (1996) and the geothermometer of Krogh (2000). These results are in accordance with the presence of primary Ca-amphibole in the eclogite and constrain the estimates of earlier investigations (Borghi 1988; Zurbriggen et al. 1997). Amphibole geothermometry on brown edenite inclusions in garnet as well as core sections of amphibole in the groundmass using the calibrations of Graham \& Powell (1984), Colombi (1988) and Ernst \& Liu (1998) led to temperatures of 720-770 ${ }^{\circ} \mathrm{C}$ thus reproducing the garnet-omphacite temperatures within the error range of the calibrations. Temperatures of the garnet-phengite geothermometer of Green \& Hellman (1982) were relatively low $\left(616-640{ }^{\circ} \mathrm{C}\right)$, which may be attributed to late re-equilibration during the retrograde overprint.

The subsequent exhumation of the eclogites resulted in the formation of the plagioclase - diopside symplectites in the groundmass. The width of the symplectite lamellae $(3-5 \mu \mathrm{m})$ points to temperatures of $690-750{ }^{\circ} \mathrm{C}$ using the geothermometer of Joanny et al. (1990) while the composition of the symplectitic diopside ( $\mathrm{Jd}_{9-16}$ ) points to pressures of 8.5-11 kbar using the jadeite-barometry of Holland (1980, 1990). These results suggest isothermal decompression (Fig. 4), which is in accordance with earlier PT-estimates of a sample from the same location (Zurbriggen et al. 1997). Remarkably, Fe-Mg-exchange equilibria between diopside in the symplectites and ad-

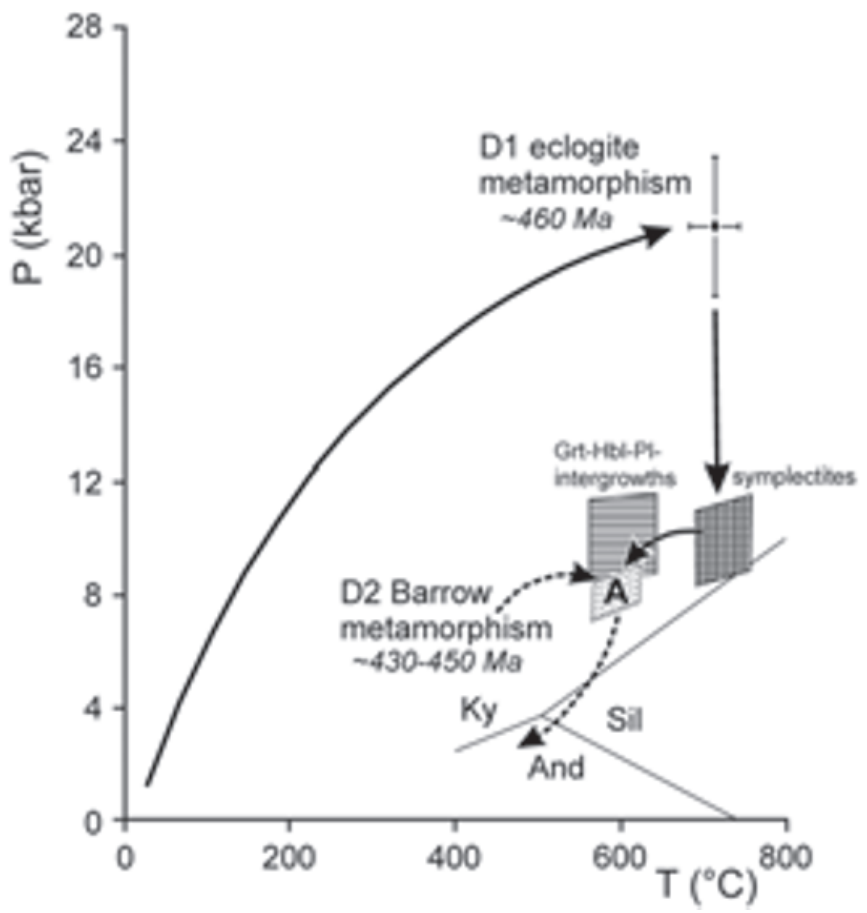

Fig. 4. PTtd-path for the metamorphics of the SCZ. Solid lines display the PT evolution of the eclogitic rocks, broken lines show the Barrovian PT path of the host rocks with peak metamorphic condition (A) after Romer \& Franz (1998) and own unpublished data. The amalgamation of the two rock suites is believed to have taken part in the lower crust. 
Tab. 3. U-Pb analytical data of zircon and rutile from eclogite sample IZ94-74 (Strona-Ceneri Zone, northern Italy)

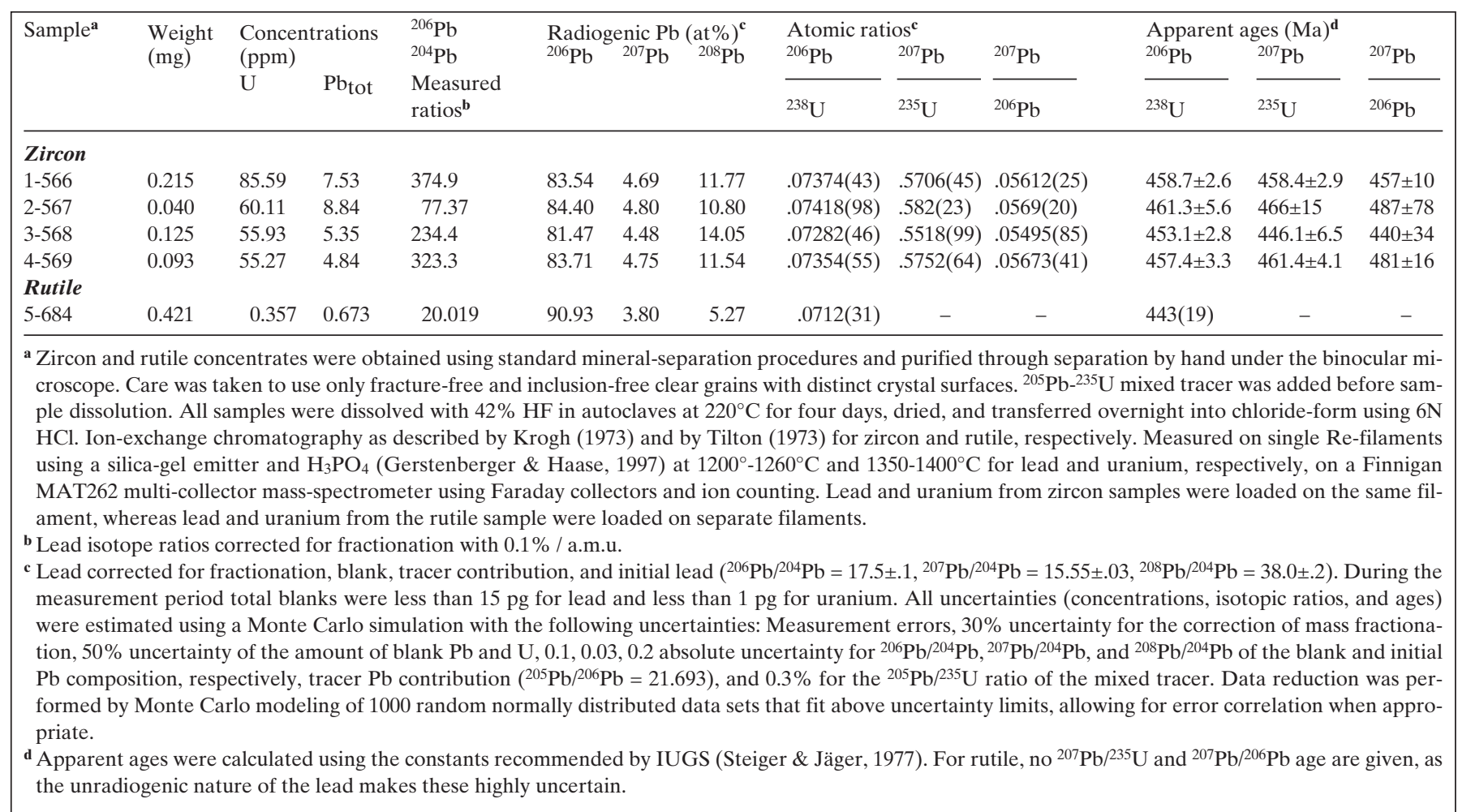

jacent garnet (e.g. Krogh 2000) as well as net-transfer-equilibria between symplectitic plagioclase, diopside and garnet (e.g. Newton \& Perkins 1982) define a wide range of PT-conditions from $500-750{ }^{\circ} \mathrm{C}$ at $9-17 \mathrm{kbar}$. This may either be due to mineral disequilibria or represent an artefact due to secondary fluorescence effects during microprobe analyses on the tiny minerals in the symplectites.

Late stage, local re-equilibration in the eclogite is indicated by the reaction rims of $\mathrm{Mg}$-hornblende, plagioclase, and quartz at the garnet rim. The application of the garnet-amphibole geothermometer of Graham \& Powell (1984) in combination with the garnet-amphibole-plagioclase geobarometer of Kohn \& Spear (1990) yields PT-conditions of $560-640{ }^{\circ} \mathrm{C}$ at 8.5-11.4 kbar (Fig. 4). These results highlight the transition from the high-temperature exhumation to the PT-conditions of the subsequent, amphibolite-facies Barrovian D2-event (Zurbriggen et al. 1997; Romer \& Franz 1998; Handy et al. 1999 and own unpublished data).

\section{3. $\mathrm{U}-\mathrm{Pb}$ age determination}

There is only one zircon population in eclogite IZ94-74. All zircon crystals show a poly-facetted equigranular habit (subtypes S7 and S12 of Pupin 1980; see Fig. 2d), which is characteristic for high-grade metamorphism (granulite and eclogite facies; cf. Vavra et al. 1999). Zircon from eclogite IZ94-74, therefore, is interpreted to have formed during high-grade metamorphism. For age determination, only perfectly clear inclusion-free crystals were analyzed. The analytical procedure and results are described in Table 3. All four analyzed zircon samples are characterized by low contents of uranium (55 to $85 \mathrm{ppm}$ ) and rather high contents of common lead (0.66 to 4.3 ppm; Table 3 ); the common $\mathrm{Pb}$ content of sample 2 being four times higher than the $\mathrm{Pb}$ content of any of the other zircon samples. The lead isotopic composition of the analyzed samples, therefore, is not very radiogenic $\left({ }^{206} \mathrm{~Pb} /{ }^{204} \mathrm{~Pb}\right.$ ranges from 77.4 to 375 ; Table 3$)$. Zircon from crustal, low-grade metamorphic, and hydrothermal rocks typically has low to very low $\mathrm{Th} / \mathrm{U}_{\text {atomic }}$ ratios $(<0.1)$; higher $\mathrm{Th} / \mathrm{U}_{\text {atomic }}$ ratios, approaching 1 are typically found in mafic magmatic and high-grade metamorphic rocks (Heaman et al. 1990; Vavra et al. 1999). The four zircon samples from eclogite IZ94-74 all have calculated $\mathrm{Th} / \mathrm{U}_{\text {atomic }}$ ratios (using age and ${ }^{208} \mathrm{~Pb}_{\mathrm{rad}} /{ }^{206} \mathrm{~Pb} \mathrm{~b}_{\mathrm{rad}}$ ) between 0.42 and 0.57 , i.e., values falling in the range of high-grade metamorphic rocks. Thus, habit and $\mathrm{Th} / \mathrm{U}$ ratios suggest that the analyzed zircon samples are metamorphic and, thus, will yield the age of highgrade metamorphism.

The analytical results are shown in Fig. 5. Three samples are perfectly concordant, whereas the fourth sample falls slightly above the concordia and does not overlap in error with the other samples. Using all four samples to define an age 


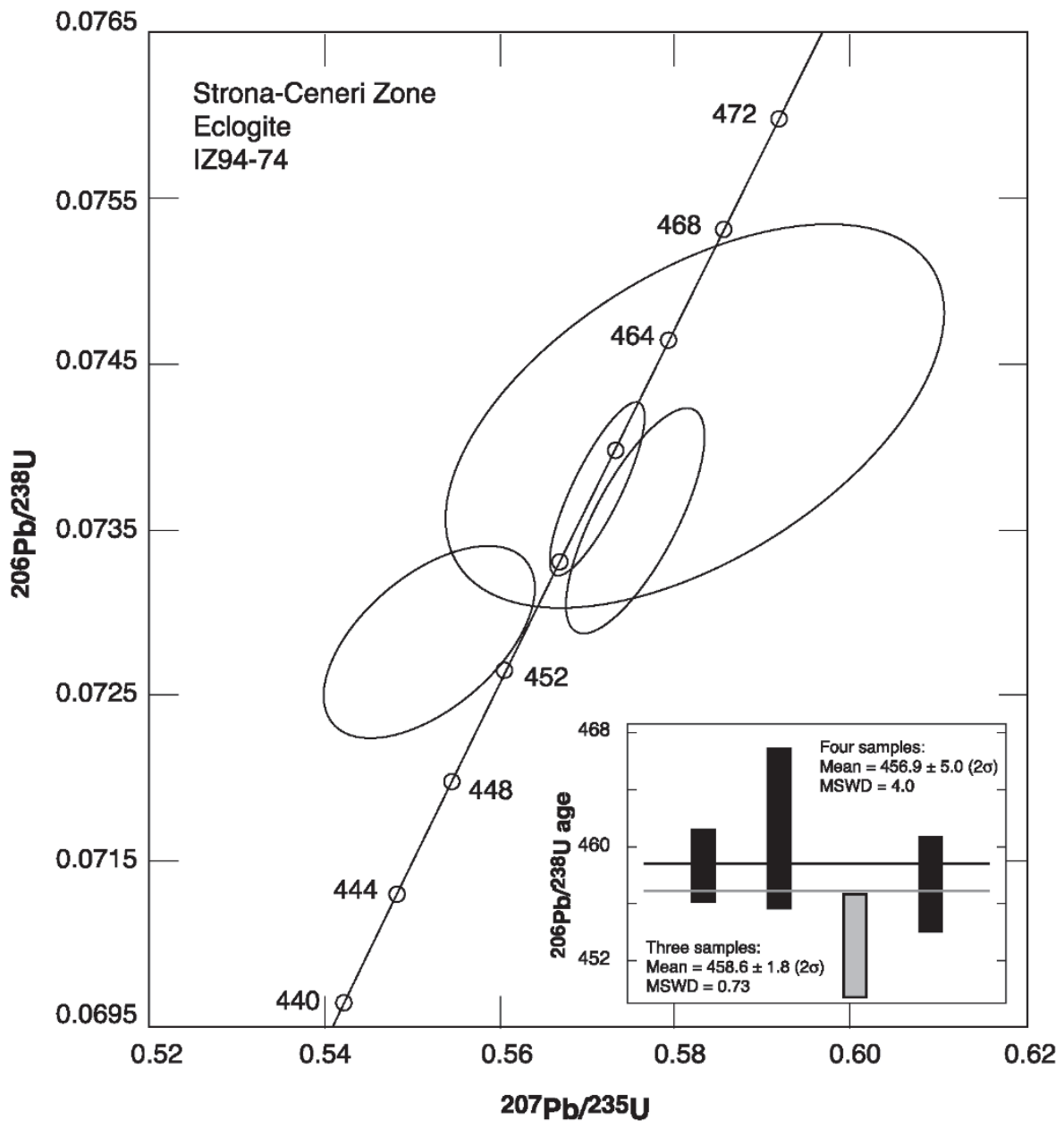

Fig. 5. ${ }^{206} \mathrm{~Pb} /{ }^{238} \mathrm{U}$ vs. ${ }^{207} \mathrm{~Pb} /{ }^{235} \mathrm{U}$ diagram for zircon from sample IZ94-74. yields a ${ }^{206} \mathrm{~Pb} /{ }^{238} \mathrm{U}$ age of $456.9 \pm 5.0 \mathrm{Ma}(2 \sigma ; \mathrm{MSWD}=4.0$, Fig. 5). Omitting sample 3, which is responsible for most of the excess scatter, results in a ${ }^{206} \mathrm{~Pb} /{ }^{238} \mathrm{U}$ age of $458.6 \pm 1.8 \mathrm{Ma}(2 \sigma$; MSWD $=0.73$ ) for the remaining three samples. Independent whether the conservative age estimate of $456.9 \pm 5.0 \mathrm{Ma}(2 \sigma)$ or the more optimistic age estimate of $458.6 \pm 1.8 \mathrm{Ma}(2 \sigma)$ is preferred, the zircon yields an Ordovician age as suggested by Handy et al. (1999) on basis of field relation and then available age data (Köppel 1974; Ragettli 1993) rather than a younger age, linking the entire region to late-Variscan tectono-metamorphic processes, as earlier suggested on the basis of ${ }^{40} \mathrm{Ar}$ ${ }^{39} \mathrm{Ar}$ amphibole step-heating experiments (290 to $340 \mathrm{Ma}$, Boriani \& Villa 1997).

Rutile in eclogite IZ94-74 has very low contents of uranium $(<1 \mathrm{ppm})$ and, therefore, developed only very low ${ }^{206} \mathrm{~Pb} /{ }^{204} \mathrm{~Pb}$ (Table 3). This unradiogenic $\mathrm{Pb}$ isotopic composition does not allow for the determination of a precise and accurate $\mathrm{U}-\mathrm{Pb}$ rutile age. Using the same isotopic composition for common $\mathrm{Pb}$ as for the zircon samples, the U-Pb systematic of rutile would yield a ${ }^{206} \mathrm{~Pb} / 238 \mathrm{U}$ age of $443 \pm 19 \mathrm{Ma}$, which is in agreement with the U-Pb zircon age and petrographic evidence demonstrating that rutile is part of the peak metamorphic mineral assemblage.

\section{Discussion and conclusions}

Structural constraints show that the early HP-event in the SCZ must have occurred before the Ordovician D2 metamorphism/magmatism. Petrologic investigations on the eclogites indicate that this event took place at $710 \pm 30^{\circ} \mathrm{C}$ and $21.0 \pm 2.5$ kbar, i.e., at quartz eclogite facies conditions. Isothermal exhumation was followed by a Barrow-type overprint under amphibolite facies conditions that affected the metabasites as well as the surrounding gneisses. U-Pb ages of $457 \pm 5 \mathrm{Ma}$ on metamorphic zircon and of $433 \pm 19$ Ma on rutile from the Monte Gambarogno eclogites clearly demonstrate the Ordovician age of the high-pressure event. Zircon habit and $\mathrm{Th} / \mathrm{U}_{\text {atomic }}$ ratio indicate that zircon formed during the high-grade metamorphism. Rutile is part of the peak metamorphic assemblage, and 
a $>460 \mathrm{Ma}$

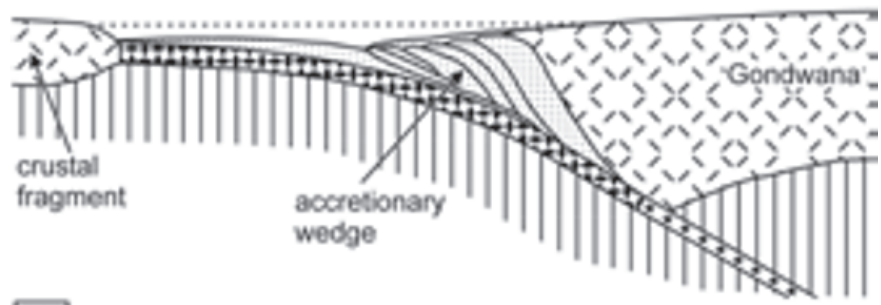

b $460 \mathrm{Ma}$
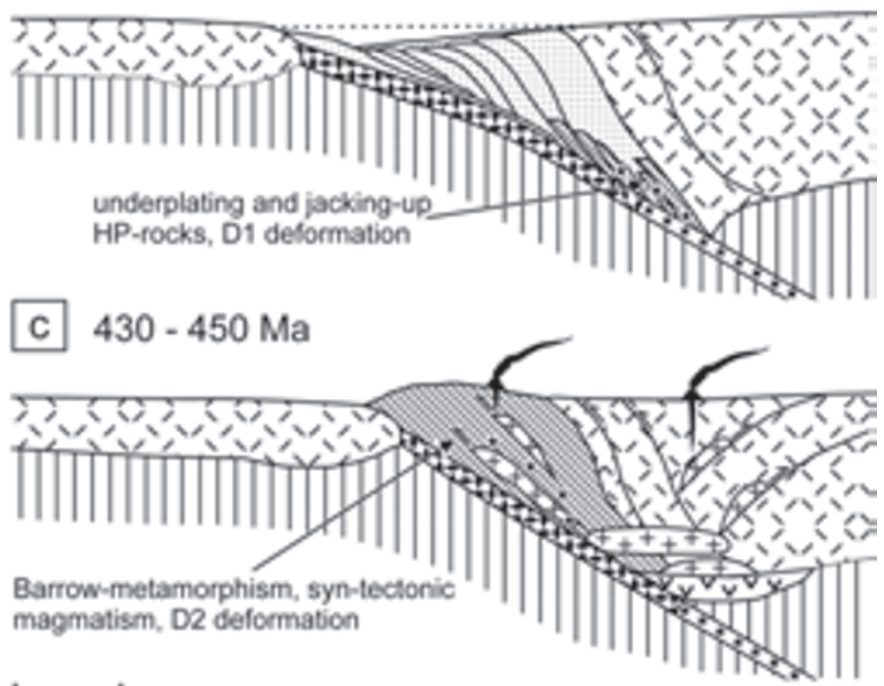

Legend

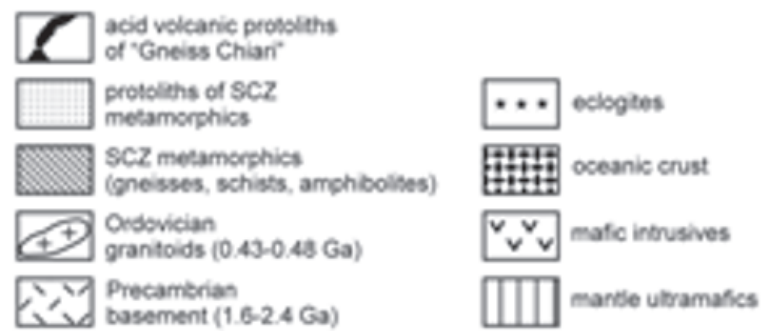

Fig. 6. Sketch of the Caledonian tectonometamorphic evolution of the SCZ

therefore, also formed during the eclogite facies metamorphic event. Although rutile only yields an imprecisely constrained age, it clearly demonstrates that eclogite facies metamorphism represents an Ordovician rather than a Cadomian event. Ordovician ages of 460-470 Ma for eclogite facies events are also known from the Gotthard massif (Oberli et al. 1994), from a Penninic basement unit north of the SCZ, and from the Eastern Alpine Ötztal Stubai complex (Hoinkes \& Thöni 1993) indicating a regional significance of this subduction.

Remarkably, the age for the Monte Gambarogno eclogites is almost identical to the age of the Ordovician Barrow-type (D2) metamorphism and the intrusion age of the orthogneisses as shown by $450-460 \mathrm{Ma} \mathrm{U}-\mathrm{Pb}$ ages of monazites and zircons from Köppel \& Grünfelder (1971) and Ragettli et al. (1993; see also Zurbriggen et al. 1997; Romer \& Franz 1998). This points to a relatively short time interval for subduction, eclogite facies metamorphism, subsequent overprint by the Barrowtype D2 event and syn-tectonic magmatism in the SCZ.

Unsolved remains the age of the D1 deformation and pressure dominated amphibolite facies metamorphism of the metapelitic xenoliths in the Ceneri gneisses. They could either have been affected by a Cadomian tectonometamorphic event, or simply have experienced an early phase of deformation during the Ordovician orogeny.

The Caledonian tectonometamorphic evolution of the Strona-Ceneri Zone is briefly summarized in Fig. 6. An Ordovician trench-arc complex along the northern periphery of Gondwanaland may have been the probable tectonic setting for the SCZ (see also Zurbriggen 1996). Subduction of oceanic crust with eclogite facies metamorphism went along with the formation of an accretionary wedge (Fig. 6a). Underthrusting and syn-metamorphic underplating in the sense of Platt (1986) led to a jacking-up of high-pressure rocks including delaminated eclogite from the oceanic crust (Fig. 6b). This process may have been connected with the early, pressure dominated amhibolite facies metamorphism and the D1 deformation. Subsequent to this, the generation of the granitoid magmatites with arc-type signatures may have been caused by mantle dehydration and mafic intrusives in the lower crust (Zurbriggen et al. 1997; see Fig. 6c). The collision with a crustal fragment (e.g., a continental microplate) overprinted the trench under Barrowtype metamorphic conditions coupled with the D2 deformation (Fig. 6c). Based on the petrology and the geochronology of the eclogites, the amalgamation of the HP-rocks and their host rocks must have occurred in the middle to lower crust. Simultaneously, syn-tectonic granitoids intruded the SCZ metamorphics while the eruptive equivalents of these magmatites may have been the protoliths for the "Gneiss Chiari" sequences in the Val Colla Zone and the Orobic basement east of the SCZ (Boriani \& Colombo 1979).

Another possible scenario for the generation of syn-tectonic magmatites with mantle affinities, crustal signatures as well as mixed types (cf. Zurbriggen 1996; Zurbriggen et al. 1997) could be the delamination of the slab with upwelling of hot asthenospheric material in the sense of Bird (1979; see also modelling of Houseman et al. 1981). Such a model could also well explain the high-temperature - low pressure event at the end of the Ordovician orogeny, which is observable by chiastolite pseudomorphs in the SCZ (Handy et al. 1999).

\section{Acknowledgements}

The paper benefited from helpful reviews of Jan Kramers (Bern) and Roger Zurbriggen (Elotex Sempach Station). Thanks are due to Dieter Rhede (GFZ Potsdam) and Axel Renno (TU BA Freiberg) for the help with microprobe analyses and Helga Kemnitz (GFZ Potsdam) for REM figure 2d. This work was inspired by our late colleague Stephan Teufel and profited from stimulating discussions in the field with Mark Handy and Roger Zurbriggen. 


\section{REFERENCES}

Bächlin, R. 1937: Geologie und Petrographie des M. Tamaro-Gebietes (südliches Tessin). Schweizerische Mineralogische und Petrographische Mitteilungen 17, 1-79.

Banno, S. 1959: Aegirinaugites from crystalline schists in Sikoku. Journal of the Geological Society of Japan 65, 652-657.

Bird, P. 1979: Continental delamination and the Colorado plateau. Journal of Geophysical Research 84, 7561-7571.

Borghi, A. 1988: Evoluzione metamorfica del settore nord-est della Serie dei Laghi (Alpi Meridionali-Canton Ticino). Rendiconti della Società Geologica Italiana 11, 165-170.

Borghi, A. 1989: L`evoluzione metamorfico-strutturale del settore nord-est della Serie dei Laghi (Alpi Meridionali). PhD thesis, University of TorinoGenova-Cagliari.

Boriani, A. \& Colombo, A. 1979: Gli “Gneiss chiari” tra la Valsesia e il Lago di Como. Rendiconti della Società Italiana di Mineralogia e Petrografia 35, 299-312.

Boriani, A. \& Villa, I. M. 1997: Geochronology and regional metamorphism in the Ivrea-Verbano Zone and Serie dei Laghi, Italian Alps. Schweizerische Mineralogische und Petrographische Mitteilungen 77, 381-401.

Boriani, A., Bigioggero, G., \& Giobbi-Origioni, E. 1977: Metamorphism, tectonic evolution and tentative stratigraphy of the "Serie dei Laghi". Geological map of the Verbania area (Northern Italy). Memories della Società Geologica Italiana 32, 22 pp.

Boriani, A., Giobbi-Origoni, E., \& del Moro, A. 1983: Composition, level of intrusion and age of the "Serie dei Laghi" orthogneisses (Northern Italy Ticino, Switzerland). Rendiconti della Società Italiana di Mineralogia e Petrografia 38, 191-205.

Boriani, A., Origoni Giobbi, E., Borghi, A., \& Caironi, V. 1990: The evolution of the "Serie dei Laghi" (Strona-Ceneri and Schisti dei Laghi): the upper component of the Ivrea-Verbano crustal section, Southern Alps, North Italy and Ticino, Switzerland. Tectonophysics 182, 103-118.

Buletti, M. 1983: Zur Geochemie und Enstehungsgeschichte der Granat-Amphibolite des Gambarognogebietes, Ticino, Südalpen. Schweizerische Mineralogische und Petrographische Mitteilungen 63, 233-247.

Carswell, D., O'Brian, P., Wilson, N., \& Zhai, M. 1997: Thermobarometry of phengite-bearing eclogites in the Dabie Mountains of central China, Journal of Metamorphic Geology 15, 239-252.

Colombi, A. 1988: Métamorphisme et géochemie des roches mafiques des Alpes ouest-centrales (géoprofil Viège-Domodossola-Locarno). Ph.D.thesis, University Lausanne $(\mathrm{CH})$.

Droop, G. T. R. 1987: A general equation for estimating $\mathrm{Fe}^{3+}$ concentrations in ferromagnesian silicates and oxides from microprobe analyses using stoichiometric criteria. Mineralogical Magazine 51, 431-435.

Ernst, W. \& Liu, J. 1998: Experimental phase-equilibrium study of Al and Ti contents of calcic amphibole in MORB- a semiquantitative thermobarometer. American Mineralogist 83, 952-969.

Fountain, D. M. 1976: The Ivrea-Verbano and Strona-Ceneri zones, northern Italy: a cross section of the continental crust - new evidence from seismic velocities. Tectonophysics 33, 145-166.

Fountain, D. M. \& Salisbury, M. H. 1981: Exposed cross sections through the continental crust: Implications for crustal structure, petrology and evolution. Earth and Planetary Science Letters 5, 263-277.

Gerstenberger, H. \& Haase, G. 1997: A highly effective emitter substance for mass spectrometric $\mathrm{Pb}$ isotope ratio determinations. Chemical Geology 136, 309-312.

Giobbi-Origoni, E., Zappone, A., Boriani, A., Bocchio, R., \& Morten, L. 1997: Relics of pre-Alpine ophiolites in the Serie dei Laghi (western Southern Alps). Schweizerische Mineralogische und Petrographische Mitteilungen 77, 187-207.

Graeter, P. 1951: Geologie und Petrographie des Malcantone (südliches Tessin). Schweizerische Mineralogische und Petrographische Mitteilungen 31, 361-482.

Graham, C. M. \& Powell, R. 1984: A garnet-hornblende geothermometer: calibration, testing, and application to the Pelona schists, southern California. Journal of Metamorphic Geology 2, 13-31.
Green, D. \& Hellmann, P. 1982: Fe-Mg partitioning between coexisting garnet and phengite at high pressures, and comments on a garnet-phengite geothermometer, Lithos 15, 253-266.

Handy, M. R. 1986: The structure and rheological evolution of the Pogallo fault zone, a deep crustal dislocation in the Southern Alps of northwestern Italy (prov. Novara), PhD thesis Universität Basel, Switzerland.

Handy, M. R., Franz, L., Heller, F. Janott, B., \& Zurbriggen, R. 1999: Multistage accretion, orogenic stacking, and exhumation of continental crust (Ivrea crustal section, Italy and Switzerland). Tectonics 18, 1154-1177.

Heaman, L. M., Bowins, R., \& Crocked, J. 1990: The chemical composition of igneous zircon suites: Implications for geochemical tracer studies. Geochimica et Cosmochimica Acta 54, 1597-1607.

Hoinkes, G. \& Thöni, M. 1993: Evolution of the Ötztal-Stubai, Scarl-Campo and Ulten basement units. In: von Raumer, J.F. \& Neubauer, F. (Eds.): Pre-Mesozoic geology in the Alps. Springer, Heidelberg, 485-494.

Holland, T. J. B. 1980: The reaction albite $=$ jadeite + quartz determined experimentally in the range of $600-1200^{\circ} \mathrm{C}$. American Mineralogist 65, 129-134.

Holland, T. J. B. 1990: Activities of components in omphacite solid solutions an application of Landau theory to mixtures. Contributions to Mineralogy and Petrology 105, 446-453.

Houseman, G. A., McKenzie, D. P., \& Molnar, P. 1981: Convective instability of a thickened boundary layer and its relevance for the thermal evolution of continental convergent belts. Journal of Geophysical Research 86, 6115-6132.

Janott, B. 1996: Kinematik und Metamorphose der Val Colla Mylonitzone im Südalpinen Grundgebirge (Tessin, Schweiz). Diploma thesis Universität Giessen, Germany.

Jarosewich, E., Nelen, J. A., \& Norberg, J. A. 1980: Reference samples for electron microprobe analysis. Geostandard Newsletter 4, 43-47.

Joanny, V., van Roermund, H., \& Lardeaux, J. M. 1990: The clinopyroxeneplagioclase symplectite in retrograde eclogites: a potential geothermobarometer. Geologische Rundschau 80, 303-320.

Kohn, M. \& Spear, F. 1990: Two new geobarometers for garnet-amphibolites, with applications to southeastern Vermont. American Mineralogist 75, 89-96.

Köppel, V. 1974: Isotopic U-Pb ages of monazites and zircons from the crustmantle transition and adjacent units of the Ivrea and Ceneri Zones (Southern Alps, Italy). Contributions to Mineralogy and Petrology 43, 55-70.

Köppel, V. \& M. Grünenfelder 1971: A study of inherited and newly formed zircons from paragneisses and granitized sediments of the Strona-Ceneri Zone (Southern Alps). Schweizerische Mineralogische und Petrographische Mitteilungen 51, 385-409.

Kretz, R. 1983: Symbols for rock-forming minerals. American Mineralogist 68, 277-279.

Krogh, E. J. 2000: The garnet-clinopyroxene geothermometer: an updated calibration. Journal of Metamorphic Geology 18, 211-219.

Krogh, T. E. 1973: A low-contamination method for hydrothermal decomposition of zircon and extraction of $\mathrm{U}$ and $\mathrm{Pb}$ for isotopic age determinations. Geochimica et Cosmochimica Acta 37, 485-494.

Leake, B. W., Wooley, A. R., Arps, C. E. S., Birch, W. D., Gilbert, M. C., Grice, J. D., Hawthorne, F. C., Kato, A., Kisch, H. J., Krivovichev, V. G., Linthout, K., Laird, J., Mandarino, J., Maresch, W. V., Nickel, E. H., Rock, N. M. S., Schumacher, J. C., Smith, D. C., Stephenson, N. C. N., Ungaretti, L., Whittaker, E. J. W., \& Youzhi, G. 1997: Nomenclature of amphiboles. Report of the subcommittee on amphiboles of the International Mineralogical Association Commission on new minerals and mineral names. European Journal of Mineralogy 9, 623-651.

Morimoto, M. 1988: Nomenclature of pyroxenes. Mineralogical Magazine 52, 535-550.

Newton, R. C. \& Haselton, H. T. 1981: Thermodynamics of the garnet-plagioclase- $\mathrm{Al}_{2} \mathrm{SiO}_{5}$-quartz geobarometer. In: Newton R. C. (Ed.): Thermodynamics of Minerals and Melts, Springer, New York, 131-147.

Newton, R. C. \& Perkins, D. I. 1982: Thermodynamic calibration of geobarometers based on the assemblages garnet - plagioclase - orthopyroxene (clinopyroxene) - quartz. American Mineralogist 67, 203-222.

Oberli, F., Meier, M., \& Biino, G. G. 1994: Time constraints on the preVariscan magmatic/metamorphic evolution of the Gotthard and Tavetsch units derived from single-zircon $\mathrm{U}-\mathrm{Pb}$ results. Schweizerische Mineralogische und Petrographische Mitteilungen 74, 483-488. 
Pidgeon, R. T., Köppel, V., \& Grünenfelder, M. 1970: U-Pb isotopic relationships in zircon suites from a para- and ortho-gneiss from the Ceneri Zone, southern Switzerland. Contributions to Mineralogy and Petrology 26, $1-11$.

Platt, J. P. 1986: Dynamics of orogenic wedges and the uplift of high-pressure metamorphic rocks. Geological Society of America Bulletin 97, 1037-1053.

Pupin, J. P. 1980: Zircon and granite petrology. Contributions to Mineralogy and Petrology 73, 207-222.

Ragettli, R. A. 1993: Vergleichende U-Xe und U-Pb Datierung an Zirkon und Monazit. PhD thesis ETH Zürich, Switzerland.

Romer, R. \& Franz, L. 1998: Ordovician Barrow-type metamorphism in the Strona-Ceneri Zone (Northern Italy) dated by U-Pb on staurolite. Schweizerische Mineralogische und Petrographische Mitteilungen 78, 383-395.

Schliestedt, M. 1980: Phasengleichgewichte in Hochdruckgesteinen von Sifnos, Griechenland. PhD thesis TU Braunschweig, Germany.

Schmid, R. 1968: Excursion guide for the Valle d'Ossola section of the IvreaVerbano zone (Prov. Novarra, Northern Italy). Schweizerische Mineralogische und Petrographische Mitteilungen 48, 305-314.

Schmid, S. M. 1993: Ivrea Zone and Adjacent Southern Alpine Basement. In von Raumer, J. F. \& Neubauer, F. (Eds.): Pre-Mesozoic Geology in the Alps, Springer, Heidelberg, 567-583.

Spicher, A. 1940: Geologie und Petrographie des oberen Val d'Isone (südliches Tessin). Schweizerische Mineralogische und Petrographische Mitteilungen 20,17-100.

Steiger, R. H. \& Jäger, E. 1977: Subcommission of geochronology: Convention on the use of decay constants in geo- and cosmochronology. Earth and Planetary Science Letters 36, 359-362.

Tilton, G. R. 1973: Isotopic lead ages of chondritic meteorites. Earth and Planetary Science Letters 19, 321-329.
Vavra, V., Schmid, R., \& Gebauer, D. 1999: Internal morphology, habit and $\mathrm{U}-\mathrm{Th}-\mathrm{Pb}$ microanalysis of amphibolite-to-granulite facies zircons: geochronology of the Ivrea Zone (Southern Alps). Contributions to Mineralogy and Petrology 134, 380-404.

Waters, D. \& Martin, H. 1993: Geobarometry of phengite-bearing eclogites. Terra Abstracts 5, 410-411.

Waters, D. \& Martin, H. 1996: Geobarometry of phengite-bearing eclogites; updated calibration at: www.earth.ox.ac.uk/davewa/ecbar.html

Zingg, A. 1990: The Ivrea crustal cross-section (northern Italy and southern Switzerland). In: Salisbury, M. H. \& Fountain, D. M. (Eds.): Exposed Cross-Sections of the Continental Crust. NATO-ASI Series C, 317, 1-20.

Zingg, A., Handy, M. R., Hunziker, J. C., \& Schmid, S. M. 1990: Tectonometamorphic history of the Ivrea Zone and its relationship to the crustal evolution of the southern Alps. Tectonophysics 182, 169-192.

Zurbriggen, R. 1996: Crustal genesis and uplift history of the Strona-Ceneri zone (Southern Alps). PhD thesis University of Bern, Switzerland.

Zurbriggen, R., Franz, L., \& Handy, M. R. 1997: Pre-Variscan deformation, metamorphism and magmatism in the Strona-Ceneri Zone (southern Alps of northern Italy and southern Switzerland). Schweizerische Mineralogische und Petrographische Mitteilungen 77, 361-380.

Zurbriggen, R., Kamber, B., Handy, M. R., \& Nägler, R. 1998: Dating synmagmatic folds: A case study of Schlingen structures in the Strona-Ceneri Zone (Southern Alps, northern Italy). Journal of Metamorphic Geology $16,403-414$.

Manuscript received January 17, 2007

Revision accepted July 24, 2007

Editorial handling: Edwin Gnos

Published Online First September 22, 2007 